\title{
Natural Self-Ligand Gamma Delta T Cell Receptors ( $\gamma \delta$ TCRs) Insight: The Potential of Induced IgG
}

\author{
Thamires Rodrigues de Sousa ${ }^{1}$ and Jefferson Russo Victor ${ }^{1,2, *(0)}$ \\ 1 Laboratory of Medical Investigation LIM-56, Division of Clinical Dermatology, Medical School, University of \\ Sao Paulo, Sao Paulo 05403-000, Brazil; sousarthamires@gmail.com \\ 2 Division of Environmental Health, FMU, Laureate International Universities, Sao Paulo 04505-002, Brazil \\ * Correspondence: victorjr@usp.br; Tel.: +55-11-30617499; Fax: +55-11-30817190
}

Received: 2 April 2020; Accepted: 12 May 2020; Published: 4 August 2020

\begin{abstract}
A $\gamma \delta \mathrm{T}$ cell acquires functional properties in response to the gamma delta $\mathrm{T}$ cell receptor $\gamma \delta \mathrm{TCR}$ signal strength during its development in the thymus. The elucidation of the potential ligands of $\gamma \delta \mathrm{T}$ cell receptors are of extreme importance; however, they are still not understood. Here we revise the actual state of the art of candidates to exert the function of $\gamma \delta \mathrm{TCR}$ ligands, and propose a theoretical contribution about new potential ligands of $\gamma \delta \mathrm{TCRs}$, based on biological and hypothetical pieces of evidence in the literature. In conclusion, we hypothetically suggest a possible role of induced antibodies according to the individual's immune status, mainly of the IgG subclass, acting as $\gamma \delta \mathrm{TCR}$ ligands. Considering that IgG production is involved in some essential immunotherapy protocols, and almost all vaccination protocols, our discussion opens a new and broad field to further exploration.
\end{abstract}

Keywords: gamma delta T; gamma delta TCR; gamma delta TCR ligands; IgG

\section{1. $\gamma \delta \mathrm{T}$ Cells}

Matured in the mouse and human thymus, $\gamma \delta \mathrm{T}$ cells are characterized by expressing $\mathrm{T}$ cell receptors TCRs composed of $\gamma$ and $\delta$ chains, and represent the major resident $\mathrm{T}$ cell population [1]. In response to activation, these cells can produce several cytokines and chemokines with several modulatory and regulatory functions on innate and adaptive immunity [2-4].

This ability to transition between innate and adaptive immunity is a typical feature of this cell population, given by non-major histocompatibility complex non-MCH restricted antigenic specificity [5], as is the capability of initiating rapid immune responses to a large number of potential tissue stressors, exerting functions related to homeostasis and the host defense of epithelial barrier tissues, and the lymphoid stress-surveillance response [1,2].

Being one of the first generated T cells in the embryonary period, $\gamma \delta \mathrm{T}$ cells quickly spread to the peripheral tissues but are not found with a high frequency in the lymphoid tissues and blood of adult individuals. On the other hand, $\gamma \delta$ T cells are detected at a higher rate in mucosal and epithelial tissues [6,7]. In the mucosal environment, these cells are activated in response to stress, including environmental challenges, infections, and malignant transformation from the surrounding tissues, and they perform many functions depending upon the location and type of stress that has occurred, in other words, $\gamma \delta \mathrm{T}$ cells act as sentinels [8].

In humans, about $5-40 \%$ of intraepithelial lymphocytes (IELs) in the paracellular space are $\gamma \delta \mathrm{T}$ cells [9]. The $\gamma \delta \mathrm{TCR}$ repertoire in the human intestine undergoes many changes during the development from fetus to adult. Thus, $\gamma \delta \mathrm{T}$ cells may mediate different functions at each stage of maturation. Since the $\gamma \delta \mathrm{TCR}$ repertoire is oligoclonal and stable over time, $\gamma \delta$ T cells may recognize a limited array of antigens that are highly conserved among different bacterial strains, mostly intracellular microbial pathogens (e.g., Listeria, Mycobacterium, Plasmodia, Toxoplasma). Additionally, $\gamma \delta$ IEL have 
been shown to produce cytokines and growth factors, and to influence epithelial cell proliferation and differentiation, as well as the mucosal development of immunoglobulin A (IgA) secreting B cells [10].

About $15-25 \%$ of T cells in the liver express the $\gamma \delta$ TCR and thus exert essential functions in the homeostasis and diseases of this organ. It is also well known as a site of the extrathymic development of $\gamma \delta \mathrm{T}$ cells during the human fetal period [11]. These cells have reportedly been shown to have their subsets altered during the progression of liver diseases, as they are probably of great importance in determining the fate of the inflammatory process in this organ [12]. A great example is $\gamma \delta \mathrm{T}$ cells contributing to hepatocyte apoptosis via Fas ligands, resulting in the engagement and recruitment of cytotoxic $\mathrm{T}$ cells in cases of hepatofibrogenesis, thereby limiting liver fibrosis [13].

Although $\gamma \delta$ T cell subsets can be defined by the expression of the $\gamma$ and $\delta$ chains, two significant $\gamma \delta \mathrm{T}$ cell subsets are defined by their capacity to produce IL-17 or IFN- $\gamma$ in mice. These subsets are not established in humans [14]. In this regard, a study has revealed that, in mice, $\gamma \delta \mathrm{T}$ cells encountering the antigen in the thymus were neither required nor inhibitory for their development, but when triggered through the T cell receptor, naive $\gamma \delta \mathrm{T}$ cells produced IL-17, whereas ligand-experienced cells produced IFN- $\gamma[15]$.

Previous studies demonstrated that IL-17-producing $\gamma \delta \mathrm{T}$ cells collaborate with an effective immune response against infections [16-19] and with the pathogenesis of autoimmunity [20,21]. These cells exert nonredundant immunological functions [22]. Otherwise, IFN- $\gamma$-producing $\gamma \delta \mathrm{T}$ cells are related to the development of murine fulminant viral hepatitis infection [23] and exert protective/regulatory functions in tumor immunity $[24,25]$.

Unlike murine models, $\gamma \delta \mathrm{T}$ cell subsets in humans are generally defined based on the V $\delta \mathrm{TCR}$ chain, narrowing down into two major populations: V $\delta 2+$ and $V \delta 2-\gamma \delta \mathrm{T}$ cells. $\mathrm{V} \delta 2+\mathrm{T}$ cells are developed mainly in the fetal liver and thymus [26,27], and are the predominant $\gamma \delta \mathrm{T}$ cell population in the peripheral blood of adult humans [28]. They can also be recruited to inflamed tissues to help with pathogen clearance or to promote inflammation. On the other hand, the V $\delta 2-\gamma \delta \mathrm{T}$ cell subset can be found in epithelial tissues, such as the skin [29] and intestines [9], and appears to form resident populations in the liver [30]. They mainly consist of V $\delta 1+\mathrm{T}$ cells, with fewer V $\delta 3+$ and $\mathrm{V} \delta 5+\mathrm{T}$ cells.

It is also important to highlight that in humans, IFN- $\gamma$-producing $\gamma \delta \mathrm{T}$ cells can mediate the innate resistance to Escherichia coli, limiting systemic immunopathology [31]. Besides that, TCR- $\gamma \delta \mathrm{T}$ cells have emerged as essential players in allogeneic hematopoietic cell transplantation (alloHCT) and immune cell therapy [32].

Since the early 1990s, the relationship between specificity and $V \gamma$ and $V \delta$ gene usage was described [28] and, currently, human $\gamma \delta$ T cells can be classified according to the expression of $\delta$ genes (81-3) and $\gamma$ genes $(\gamma 2-5, \gamma 8, \gamma 9$, and $\gamma 11)$ [33]. Murine $\gamma \delta$ TCR chain expression can be related to a tissue site (e.g., $\gamma 1, \gamma 4$, and $\gamma 6$ in the lung), and this differential expression influences the antigen-specific recognition properties of tissue-infiltrated $\gamma \delta \mathrm{T}$ cells between each tissue and, consequently, influences their collaboration with the development of an adaptive immune response [3].

Besides, in the context of adaptive immune responses, it was demonstrated that $\gamma \delta \mathrm{T}$ cells can favor murine antibody production by B cells by secreting IL-4 and IL-10 [34].

The $\gamma \delta \mathrm{TCR}$ signaling during the early stages of maturation in the thymus can influence the mature $\gamma \delta \mathrm{T}$ cells' cytokine secretion profile [35]. With the use of a molecule that can act as a ligand of $\gamma \delta \mathrm{TCRs}$, such as the major histocompatibility complex (MHC) class Ib ligands (H2-T10/22), it was demonstrated that $\gamma \delta \mathrm{TCR}$ interaction can play an essential role in shaping the TCR repertoire of $\gamma \delta \mathrm{T}$ cells [36].

These observations indicate that the elucidation of the potential ligands of $\gamma \delta \mathrm{TCRs}$ and their relations with the induction of functional properties in $\gamma \delta \mathrm{T}$ cells is of extreme importance. However, this has been discussed by renowned scientists in the literature since the late 1980s [37,38], and even after some evolutionary analysis, the mechanisms involved in $\gamma \delta \mathrm{TCR}$-dependent $\gamma \delta \mathrm{T}$ cell activation are still not understood [33]. The search for the identification of $\gamma \delta \mathrm{TCR}$ ligands was named "the quest to solve a 500-million-year-old mystery" [39]. 
Taking into consideration the modulatory effects mediated by $\gamma \delta$ T cells in the mechanism of immune inflammation, here we briefly revise the state of the art and propose a theoretical contribution to generate some discussions about new potential ligands of $\gamma \delta \mathrm{TCR}$. With this purpose, we collected biological and hypothetical pieces of evidence from the literature.

\section{Antigen Recognition Mechanism}

As is known, $\alpha \beta T$ cells recognize antigens as antigen fragments after being processed by antigen-presenting cells (APC), followed by the binding of these fragments to various sites on the major histocompatibility complex (MHC) molecule of the APC, and posterior presentation at the cell surface to the TCR, and then activation and proliferation of the T cells [40-44]. However, there are far fewer pieces of evidence showing the mechanisms involved in antigen recognition by $\gamma \delta \mathrm{T}$ cells. However, it is essential to remember that these two lineages of cells differ not just at a molecular level, they also have a different antigenic repertoire, even though specific antigens are capable of stimulating both populations.

In this context, two significant points allow us to tell the difference between these two populations within the process of antigen recognition. The first is that some $\gamma \delta \mathrm{T}$ cells do not seem to require the classical MHC for antigen recognition, since the majority of $\gamma \delta \mathrm{T}$ cell hybridomas do not require the MHC for activation [45]. Furthermore, studies from another group have gathered data on a murine TCR gamma delta clone (TgI4.4) capable of recognizing a herpes simplex virus type 1 (HSV-1) transmembrane glycoprotein in an MHC class I- and II-independent manner [46]. On the other hand, there are shreds of evidence that $\gamma \delta$ T cells may recognize some antigens, like tetanus toxoid, in an MHC-restricted fashion [47].

Although some $\gamma \delta \mathrm{T}$ cells were able to recognize proteins without processing, such as mouse class II MHC molecule IE ${ }^{\mathrm{k}}$, T10, T22, and herpes simplex virus glycoprotein I, others were unable to recognize peptides bound to these proteins [48-51]. In addition, these studies have demonstrated that some $\gamma \delta$ T cell clones seem to recognize antigens without the need for intracellular antigen processing, which means this recognition process is made directly on the surface.

Taken together, these pieces of evidence allow us to suggest that $\gamma \delta \mathrm{T}$ cells can recognize unprocessed antigens at the cell surface, exempting APCs as a requirement for antigen recognition by those cells. However, APCs may exert other functions when they can be stimulated by the products of gamma delta $T$ cell activation into producing cytokines and growth factors, collaborating with the enhancement of the ongoing immunological response.

\section{Evidenced and Proposed $\gamma \delta$ TCR Ligands}

As discussed above, $\gamma \delta \mathrm{TCR}$ signaling can determine the activity of $\gamma \delta \mathrm{T}$ cells $[14,52,53]$, therefore a precise functional understanding of $\gamma \delta$ T cells depends on the elucidation of the molecules capable of triggering their activation via $\gamma \delta \mathrm{TCRs}$.

Reasoning from this fact, here we will not discuss all pieces of the evidence of the direct interaction of several ligands with $\gamma \delta$ TCRs [54-58], but mainly those that are likely to generate future mechanistic or biological approaches in vivo.

First and foremost, a very recent study was able to demonstrate that $\gamma \delta$ TCR ligands can be expressed by several cells, including both human tumor cell lines and individual human primary cells. This study could also illustrate the spectrum of ligand(s) expression for human synovial V $\delta 1 \gamma \delta \mathrm{T}$ cells, as well as the physiology that regulates their expression, but it did not accurately identify the molecules that can act as $\gamma \delta$ TCR ligands in those cells [59].

In this context, it was shown that spatially distinct regions of $\gamma \delta \mathrm{TCRs}$, as demonstrated by the hypervariable region 4 (HV4) of $\mathrm{V} \gamma 4$ chains, can determine the antigen responsiveness of $\gamma \delta \mathrm{T}$ cells, increasing the complexity of the understanding of $\gamma \delta T C R$ ligand recognition [60].

It has been shown that murine $\gamma \delta$ T cells depend on the type of adjuvant used in immunization to shift the production of IL-17 [61]. On the other hand, it was described that human $\gamma \delta$ T cell subsets can 
recognize both natural and synthetic phosphoantigens (pAgs) [62]. However, the mammalian molecule isopentenyl pyrophosphate (IPP) stimulates $\gamma \delta$ T cells at a 10,000-fold higher concentration compared to phosphoantigens derived from bacteria. This last observation suggests that IPP cannot exert a physiological role as a $\gamma \delta \mathrm{TCR}$ ligand [63]. Additionally, a report has indicated that pAgs do not interact directly with $\gamma \delta \mathrm{TCRs}$, in fact, the $\mathrm{V} \gamma 9 \mathrm{~V} \delta 2 \mathrm{~T}$ cell activation is due to the recognition of an allosteric change in the extracellular domain of a cell surface molecule, butyrophilin 3A1 [64]. The F1-ATPase molecule was proposed as a $\gamma \delta \mathrm{TCR}$ ligand in a tumor recognition study [65], but the evidence for this is still incomplete. A detailed discussion about $\gamma \delta \mathrm{TCR}$ ligands, summarized in Figure 1, and the knowledge generated in both species, will follow.

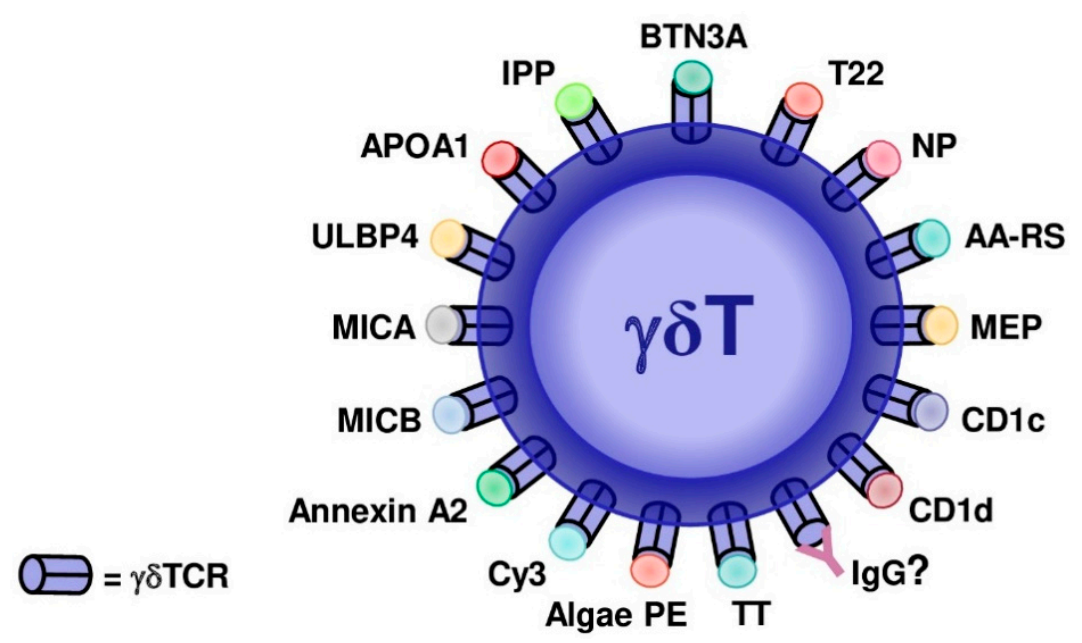

Figure 1. Evidenced and proposed $\gamma \delta \mathrm{TCR}$ ligands in mice and humans. Butyrophilin-3 (BTN3A), nonclassical MHC molecule T22, 4-hydroxy-3-nitrophenylacetyl (NP), aminoacyl-tRNA synthetases (AA-RS), monoethyl phosphate (MEP), CD1c, CD1d, toxoid of Clostridium tetani (TT), algal phycoerythrin (PE), cyanine 3 (Cy3), annexin A2, MICB (MHC class I chain-related protein B), MICA (MHC class I chain-related protein A), ULBP4, APOA-1 (apolipoprotein A-1), isopentenyl pyrophosphate (IPP), and IgG are illustrated. ? = proposed non-evidenced ligand.

\subsection{Algal Phycoerythrin (PE)}

A noted B cell antigen, the algal protein phycoerythrin (PE), can act as a murine and human $\gamma \delta$ TCR antigen [66]. In this study, it was demonstrated that the recognition of algal PE by activated naive $\gamma \delta$ T cells induces the production of IL-17 and yields the functionality to respond to cytokine signals, collaborating with the perpetuation of the immune response [66].

\subsection{Annexin A2}

More recently, using in vitro experiments in which tumor cells were exposed to various stress situations, it was observed that $\gamma \delta \mathrm{T}$ cells could recognize tumor cells. This direct recognition is mediated by a cell stress-related molecule, annexin A2. However, it seems that it occurs only with a specific subset of $\gamma \delta \mathrm{T}$ cells, the $\mathrm{V} \gamma 8 \mathrm{~V} \delta 3 \mathrm{TCR}$-expressing $\gamma \delta \mathrm{T}$ cells [67].

\subsection{BTN3A (Butyrophilin-3)}

A study using cell stress-related molecule phosphoagonist (PAg) up-regulation in tumor and mycobacteria-infected cells, demonstrated that a human $\gamma \delta$ T cell could also recognize butyrophilin-3 (BTN3A) molecules. However, similar to annexin A2, it seems to occur only with a specific subset of $\gamma \delta$ $\mathrm{T}$ cells, in this case, the $\mathrm{V} \gamma 9 \mathrm{~V} \delta 2 \mathrm{TCR}$-expressing $\gamma \delta \mathrm{T}$ cells [68]. Luckily, $\mathrm{V} \gamma 9 \mathrm{~V} \delta 2 \mathrm{~T}$ cells represent the major $\gamma \delta \mathrm{T}$ cell subset in human peripheral blood, with values ranging from $50 \%$ to $95 \%$ of $\gamma \delta \mathrm{T}$ cells, besides the fact that they stand out as being able to sense several infected and malignant cells [69]. 


\section{4. $T 22$}

It was demonstrated that the non-classical MHC molecule, T22, could act as a ligand for $\gamma \delta \mathrm{TCRs}$ in mice [70] and the MHC-like molecule, CD1, in mice and humans [71]. Performing a study that aimed to identify CD1d-sulfatide-specific T cells in healthy individuals, Bai L and collaborators surprisingly observed that the majority of fresh sulfatide-specific T cells belonged to the $\gamma \delta$ lineage, and they mainly expressed V $\delta 1$ chains in their TCRs [72]. This study provided the first demonstration of MHC-like-restricted, antigen-specific recognition by $\gamma \delta$ TCRs [72].

\section{5. $C D 1 c$}

The CD1c, a molecule expressed by human dendritic cells (DCs) and B cells when presenting antigens to T cells, can be recognized by $\gamma \delta \mathrm{TCR}$ when loaded with Mycobacterium tuberculosis phosphomycoketide [73]. This same study evidenced that the V $\delta 1$ domain participates in recognition by $\gamma \delta$ TCRs and demonstrates that CD1c can complex with lipids, including lysophosphatidylcholine, sulfatide, and mannosyl-phosophomycoketide [73].

Although these molecules cannot mediate in vivo interaction with $\gamma \delta \mathrm{TCRs}$, shaping their maturation process, they may be especially crucial in the recognition of pathogens by peripheral $\gamma \delta \mathrm{T}$ cells. Otherwise, the definition of $\gamma \delta$ T cells' functions mainly occurs during theirmaturation in the thymus, suggesting that other ligands that can reach this organ are involved in the development of $\gamma \delta$ $\mathrm{T}$ cell functions.

\subsection{Haptens}

Studies about $\gamma \delta \mathrm{T}$ cell hapten recognition emerged from the idea that these cells possibly recognize antigens similarly to B cells [48]. A study using immunized mice with Cy3-chicken gamma globulin (Cy3-CGG) in aluminum hydroxide demonstrated that haptens, such as cyanine 3 (Су3) and 4-hydroxy-3-nitrophenylacetyl (NP), can be recognized directly by specific $\gamma \delta$ TCRs, and are able to induce a T cell response [74]. Thus, these molecules are capable of up-regulating CD44hi and CD62L $\mathrm{L}^{\mathrm{lo}}$, which is equal to an activated phenotype in $\gamma \delta$ T cells.

\subsection{Non-Peptides}

The initial observation about non-peptide recognition was obtained with a non-peptide antigen derived from $M$. tuberculosis that could be recognized by murine and human $\gamma \delta$ T cells [75]. From there, a subsequent study demonstrated that a variety of non-peptide molecules could stimulate human $\gamma \delta \mathrm{T}$ cells [76]. In the same study, it was shown that monoethyl phosphate (MEP), a synthetic alkyl phosphate, was able to activate these cells and stimulate their proliferation in vitro [76]. In both cases, all $\gamma \delta \mathrm{T}$ cells stimulated by these molecules expressed $\mathrm{V} \gamma 2 / \mathrm{V} \delta 2 \mathrm{TCRs}$.

In a comparative approach, it was demonstrated that mycobacterial antigens recognized by $\gamma \delta \mathrm{T}$ cells were chemically and chromatographically similar to MEP, and both were able to expand primary Vy2/V82 T cells [76].

The human stress antigens MICA and MICB are MHC class I-related molecules originally described as ligands of NKG2D receptors expressed in NK cells. They have also been described as ligands of $\gamma \delta \mathrm{T}$ cells that express the variable region V $\delta 1$, therefore acting as stress-induced self-antigens [77]. However, this correlation is limited to the intestinal epithelium because it corresponds to the environment where this subset of $\gamma \delta$ T cells is prevalent, and where MICA and MICB are mainly expressed. The same study also showed that there is a correlation between these $\mathrm{T}$ cells and epithelial tumors, which, regardless of their type, express MICA/MICB. The reason behind this correlation is that the more MICA/MICB is expressed, the higher the number of $\gamma \delta \mathrm{T}$ cells found in the tissue [78]. In this regard, another study using soluble MICA tetramers as a binding reagent to demonstrate specific interactions with various V $\delta 1 \gamma \delta$ TCRs expressed on T cell lines lacking NKG2D, showed that MICA delivers both the TCR-dependent signal and the NKG2D-dependent costimulatory signal. This dual function may be 
useful to prevent inaccurate $\gamma \delta \mathrm{T}$ cell activation in cases of cross-reactivity with other cell surface compounds [79].

Another interesting molecule worth mentioning is ULBP4, which is also a ligand for NKG2D, along with MICA/MICB. In a study conducted by Kong's group, ULBP4 not only can play a role as a ligand for $\mathrm{TCR} \gamma \delta$, binding directly to it, but can also trigger the expansion of gamma delta $\mathrm{T}$ cells from tumor-infiltrating lymphocytes in humans [80].

Since molecules expressed on the surface of tumoral cells seem to be seen as an attractive criterion to draw the attention of $\gamma \delta$ T cells, apolipoprotein A-1 (APOA-1) should not be left out of this discussion. A tumor recognition study led by Scotet's group has shown that when in the presence of APOA-1, tumors expressing F1-ATPase can trigger the activation of $\mathrm{V} \gamma 9 \mathrm{~V} \delta 2 \mathrm{~T}$ cells by selectively binding to the V $\gamma 9 \mathrm{~V} \delta 2$ TCR [65].

\subsection{Peptides}

Despite the notoriety of non-peptidic antigens, there is a variety of protein-derived molecules that can trigger $\gamma \delta \mathrm{T}$ cell activation. In humans, the earliest evidence points to the tetanus toxoid of Clostridium tetani, capable of stimulating specific $\gamma \delta \mathrm{T}$ cell responses [47]. Another study has shown that processed Ig $\lambda$ light chains in humans [81], and even processed insulin in mice [82], are also recognized by $\gamma \delta \mathrm{T}$ cells. Additionally, cell surface-expressed proteinaceous ligands have been identified, including the classical MHC I and II molecules, as well as the non-classical MHC I-related molecule, T22, in mice [70], CD1c in humans [73], and CD1d in both mice and humans [72], as discussed above.

\subsection{Aminoacyl-tRNA Synthetases (AA-RSs)}

Another study that aimed to investigate the antigen specificity of $\gamma \delta$-TCRs, in humans that develop myositis, could demonstrate that $\mathrm{V} \gamma 1.3 \mathrm{~V} \delta 2$-TCR (M88) recognizes aminoacyl-tRNA synthetases (AA-RSs), an antigen that can also be targeted by an autoantibody called anti-Jo-1. The observation that AA-RSs are targeted by a $\gamma \delta \mathrm{T}$ cell and by an autoantibody reveals an unprecedented link between $\mathrm{T}$ cell and antibody responses in autoimmune myositis [83].

\subsection{Dectin-1 (CLEC7A)}

C-type lectin domain family 7 member A, also called dectin-1, is a human protein encoded by the CLEC7A gene that was initially identified by subtractive cDNA cloning, using mRNA extracted from murine DCs [84]. In addition to inducing Th17 cells, it was demonstrated that dectin-1 could also directly trigger the production of IL-17 by a subset of $\gamma \delta$ T cells [85].

In 2014, it was demonstrated in a murine model of hepatic regeneration with the disruption of TCR $\delta$ and Clec7a, that $\gamma \delta$ T cells can regulate this process through the production of IL-22 and IL-17. This mechanism occurs by direct effects on hepatocytes and by the promotion of a regenerative phenotype in hepatic leukocytes. These observations suggest that dectin- 1 is required for $\gamma \delta \mathrm{T}$ cell-promoted hepatic regeneration [86].

Table 1 summarizes the experimental pieces of evidence about $\gamma \delta \mathrm{TCR}$ ligands, considering the differences between mouse and human $\gamma \delta$ T cells.

\subsection{IgG Antibodies as $\gamma \delta T C R$ Ligands}

In almost all of the studies cited above, the search for a $\gamma \delta T C R$ ligand was focused on the identification of membrane-like or membrane-expressed molecules with no discussion about ligands that can have soluble forms, such as antibodies.

IgG antibodies are versatile molecules expressed by B cells and can also be detected in other cell membranes after interaction with Fc $\gamma$ receptors. This molecule is also secreted by B cells, and its soluble form can reach almost all of the tissues of an organism. 
Table 1. $\gamma \delta \mathrm{TCR}$ ligands with biological effects described in the literature. Classes of ligands and their effects on humans and mice.

\begin{tabular}{|c|c|c|c|c|}
\hline Proposed Ligand & Class & $\begin{array}{l}\text { Effect in Human } \gamma \delta \\
\text { T Cells }\end{array}$ & $\begin{array}{c}\text { Effect in Mouse } \gamma \delta \mathrm{T} \\
\text { Cells }\end{array}$ & References \\
\hline $\begin{array}{c}\text { Aminoacyl-tRNA } \\
\text { synthetases (AA-RSs) }\end{array}$ & Enzyme & $\begin{array}{l}\text { Destruction of } \\
\text { skeletal muscle fibers } \\
\text { in myositis. }\end{array}$ & $\begin{array}{l}\text { Not reported in the } \\
\text { literature due to the } \\
\text { incapability ofgenerating } \\
\text { transgenic mice. }\end{array}$ & [83] \\
\hline $\begin{array}{l}\text { Algal phycoerythrin } \\
\text { (PE) }\end{array}$ & Protein & Production of IL-17. & Production of IL-17. & [66] \\
\hline Annexin A2 & Protein & $\begin{array}{l}\text { Proliferation of a } \\
\text { V } \delta 2^{\text {neg }} \gamma \delta \text { T-cell } \\
\text { subset. }\end{array}$ & $\begin{array}{l}\text { Not reported in the } \\
\text { literature. }\end{array}$ & [67] \\
\hline $\begin{array}{l}\text { Butyrophilin-3 } \\
\text { (BTN3A) }\end{array}$ & Peptide & $\begin{array}{l}\text { Intracellular PAg } \\
\text { accumulation } \\
\text { leading to activation } \\
\text { of } \mathrm{V} \gamma 9 \mathrm{~V} \delta 2 \mathrm{~T} \text { cells. }\end{array}$ & $\begin{array}{l}\text { Not reported in the } \\
\text { literature. }\end{array}$ & {$[68,69]$} \\
\hline CD1c & MHC molecule & $\begin{array}{l}\text { Lysis of } \\
\text { CD1c-expressing } \\
\text { tumor cells. }\end{array}$ & $\begin{array}{l}\text { Not reported in the } \\
\text { literature. }\end{array}$ & {$[71,72]$} \\
\hline Cyanine 3 (Су3) & Hapten & $\begin{array}{l}\text { Not reported in the } \\
\text { literature. }\end{array}$ & $\begin{array}{l}\text { Up-regulation of CD44 in } \\
\text { Cy3-specific } \gamma \delta \mathrm{T} \text { cells, } \\
\text { IL-17 production, and } \\
\text { expression of receptors for } \\
\text { IL-1 and IL-23. }\end{array}$ & [74] \\
\hline $\begin{array}{c}\text { 4-hydroxy-3- } \\
\text { nitrophenylacetyl (NP) }\end{array}$ & Hapten & $\begin{array}{l}\text { No reported in the } \\
\text { literature. }\end{array}$ & $\begin{array}{l}\text { Up-regulation of CD44hi } \\
\text { and CD62Llo (activated } \\
\text { phenotype). }\end{array}$ & [74] \\
\hline $\begin{array}{l}\text { Mycobacterial antigen } \\
\text { from } M \text {. tuberculosis }\end{array}$ & Non-peptide & $\begin{array}{l}\text { Activates the } \\
\text { V } \gamma 2 / \mathrm{V} \delta 2+\text {. }\end{array}$ & $\begin{array}{l}\text { In vivo activation of } \gamma \delta \mathrm{T} \\
\text { and participation in the } \\
\text { primary immune response } \\
\text { to } M \text {. tuberculosis. }\end{array}$ & [75] \\
\hline $\begin{array}{l}\text { Monoethyl phosphate } \\
\text { (MEP) }\end{array}$ & Non-peptide & $\begin{array}{l}\text { Activates the } \\
\text { V } \gamma 2 / \mathrm{V} \delta 2+\text {. }\end{array}$ & $\begin{array}{l}\text { Not reported in the } \\
\text { literature since } \mathrm{V} \gamma 2 \mathrm{~V} \delta 2 \mathrm{~T} \\
\text { cells are restricted to } \\
\text { primates. }\end{array}$ & [76] \\
\hline TC22 & MHC molecule & $\begin{array}{l}\text { Not reported in the } \\
\text { literature. }\end{array}$ & $\begin{array}{l}\text { G8 bound T22 almost } \\
\text { exclusively through its } \\
\text { CDR3 loop with only } \\
\text { minor contacts from other } \\
\text { CDR loops. }\end{array}$ & [70] \\
\hline MICA/MICB & $\begin{array}{l}\text { MHC class } \\
\text { I-related } \\
\text { molecules }\end{array}$ & $\begin{array}{c}\text { Increase in the } \\
\text { number of } \gamma \delta \mathrm{T} \text { cells } \\
\text { found in the tumoral } \\
\text { tissue. }\end{array}$ & $\begin{array}{l}\text { Not reported in the } \\
\text { literature. }\end{array}$ & [77-79] \\
\hline ULBP4 & $\begin{array}{l}\text { MHC } \\
\text { class-related } \\
\text { molecules }\end{array}$ & $\begin{array}{l}\text { Expansion of } \gamma \delta \mathrm{T} \\
\text { cells from } \\
\text { tumor-infiltrating } \\
\text { lymphocytes. }\end{array}$ & $\begin{array}{l}\text { Not reported in the } \\
\text { literature. }\end{array}$ & [80] \\
\hline $\begin{array}{l}\text { Apolipoprotein A-I } \\
\text { (APOA-I) }\end{array}$ & Protein & $\begin{array}{l}\text { Activation of } \\
\mathrm{V} \gamma 9 \mathrm{~V} \delta 2 \mathrm{~T} \text { cells by } \\
\text { tumors expressing } \\
\text { F1-ATPase in the } \\
\text { presence of APOA-1. }\end{array}$ & $\begin{array}{l}\text { Not reported in the } \\
\text { literature. }\end{array}$ & [65] \\
\hline $\begin{array}{l}\text { Dectin-1 } \\
\text { (CLEC7A) }\end{array}$ & Protein & & $\begin{array}{c}\text { Triggers the production of } \\
\text { IL-17 by a subset of } \gamma \delta \mathrm{T} \\
\text { cells. }\end{array}$ & [86] \\
\hline
\end{tabular}

Although, theoretically, these molecules may also interact specifically with $\gamma \delta \mathrm{TCRs}$, studies evaluating this hypothesis are very scarce in the literature. Among the few pieces of evidence in this 
issue, it was demonstrated that a monoclonal antibody that can recognize murine $\gamma \delta$ TCRs (clone UC7-13D5), induces the in vivo generation of $\gamma \delta \mathrm{T}$ cells [87]. Another study demonstrated that an anti- $\gamma \delta \mathrm{TCR}$ antibody can be used to expand $\gamma \delta \mathrm{T}$ cells in vitro and may be used as cellular therapy in the treatment of lung cancer [88] or lymphoid malignancies [89]. These observations generate a very interesting fraction of new possibilities on each antibody that can act as a ligand of $\gamma \delta \mathrm{TCRs}$, and need to be discussed across a broader spectrum as will follow.

In 2017, it was hypothetically suggested that IgG could be a natural ligand of lymphocyte receptors, including $\gamma \delta \mathrm{TCRs}$, and mediate some functional modulations of $\gamma \delta \mathrm{T}$ cells according to an individual's IgG repertoire. This hypothesis considered that this molecule could reach primary lymphoid organs, including the thymus, in soluble and membrane-expressed forms, and accurately interact with the clonal receptors expressed on those cells [90].

Very briefly, what underlies this hypothesis is the fact that mammalian organisms naturally have the potential to spontaneously produce IgG antibodies that express idiotypes capable of recognizing any natural protein [91]. This characteristic includes all self-proteins, hence all receptors are expressed in $\gamma \delta \mathrm{T}$ cells since their initial stages of maturation.

More recently, this hypothesis became experimentally evidenced with the demonstration that both murine and human IgG can modulate the frequency of IL-17-producing $\gamma \delta \mathrm{T}$ cells depending on the IgG donor's immune status [92]. In the same study, it was demonstrated for the first time that murine IgG could directly interact with the thymic $\gamma \delta \mathrm{T}$ cell membrane (in the absence of Fc $\gamma$ Rs), although the co-localization of IgG and $\gamma \delta \mathrm{TCR}$ has not been evaluated. Another recent study has also demonstrated that IgG can modulate the production of IFN- $\gamma$ and IL-10 by human thymic $\gamma \delta \mathrm{T}$ according to the donor's immune status [93]. Corroborating this hypothesis, similar studies evaluating the potential of IgG molecules as mediators of modulatory effects on lymphocytes during their maturation have demonstrated several effects on human TCD4, TCD8, iNKT, and B cells [94-98].

A direct relation between $\gamma \delta \mathrm{T}$ cell activation and the murine antibody-mediated immune response in an antigen-specific manner was also recently revealed [99]. In this study, the possible role of IgG as a $\gamma \delta$ TCR ligand was not evaluated, but the relationship between antigen-specific antibodies and $\gamma \delta \mathrm{T}$ cell activation in two murine models was shown [99]. This last piece of evidence demonstrated the importance of $\gamma \delta \mathrm{T}$ cells in protein-induced immune responses and autoimmunity.

So far, these observations cannot adequately explain the IgG role as a $\gamma \delta \mathrm{TCR}$ ligand, but they could have been considered within the list of candidates for ligands of these receptors, as recently revised [39].

Considering that under in vivo conditions, IgG can reach thymic lymphocytes during its maturation process [100-103], these recent studies open a broad discussion, suggesting that IgG can exert a role modulating the maturation of $\gamma \delta \mathrm{T}$ cells at primary sites. Furthermore, the functional modulation mediated by IgG may vary according to individual repertoire specificity; it is possible that the role of $\gamma \delta$ T cells in inducing tissue inflammation is influenced by the IgG response to antigen exposition and its natural $\mathrm{IgG}$ repertoire.

Very recently, a hypothesis called the "hooks without bait" theory was presented in the literature to discuss the role of natural and induced IgG repertoires as modulatory ligands, not only for $\gamma \delta \mathrm{T}$ cells, but in a broader context that includes T and B cells [104].

These observations are important in humans because of their wide variation in ambient exposure conditions and natural antibody repertoires, compared to murine observations obtained under controlled ambient exposure conditions and, therefore, homogeneous antibody diversity.

If the repertoire of IgG (the individual's group of idiotypes) can influence $\gamma \delta \mathrm{T}$ cell functions by interacting with $\gamma \delta \mathrm{TCRs}$, they will modulate $\gamma \delta$ T cells according to the expressed $\gamma$ and $\delta$ chains. As discussed above, the expression of $\gamma$ and $\delta$ chains is related to homing, functionality, and the antigen-specific recognition properties of $\gamma \delta \mathrm{T}$ cells. Therefore, if the IgG repertoire could indeed specifically interact with $\gamma \delta \mathrm{TCR}$, this could result in the functional modulation of $\gamma \delta \mathrm{T}$ cells according to their antigen recognition pattern.

If confirmed, this hypothesis will corroborate the elucidation of several aspects of $\gamma \delta \mathrm{T}$ cell biology. 
These biological aspects include the functional roles of $\gamma \delta \mathrm{T}$ cells in inflammation induced by different antigens [105], the $\gamma \delta$ TCR repertoire changes in response to infections [106], the constant $\gamma \delta \mathrm{TCR}$ triggering of $\gamma \delta \mathrm{T}$ cells in vivo [107], the relationship between intestinal microbiota and $\gamma \delta \mathrm{T}$ cell functions [108], and the observation that the repertoire of intraepithelial $\gamma \delta \mathrm{T}$ cells is not biased toward thymic antigens [109].

A recent study demonstrated an additional $\gamma \delta \mathrm{T}$ cell characteristic that can be influenced by an individual's IgG repertoire. It was described that an $\gamma \delta \mathrm{TCR}^{\prime}$ s repertoire shifts the $\mathrm{V} \gamma$ - and $\mathrm{V} \delta$-usage upon aging [110]. Considering that an individual's IgG is certainly permissive to repertoire shifts with aging if IgG can indeed act as a ligand of $\gamma \delta$ TCRs, IgG will influence the frequency of $\gamma$ and $\delta$ chain expression and modulate $\gamma \delta$ T cell-mediated mechanisms, as suggested in Figure 2.

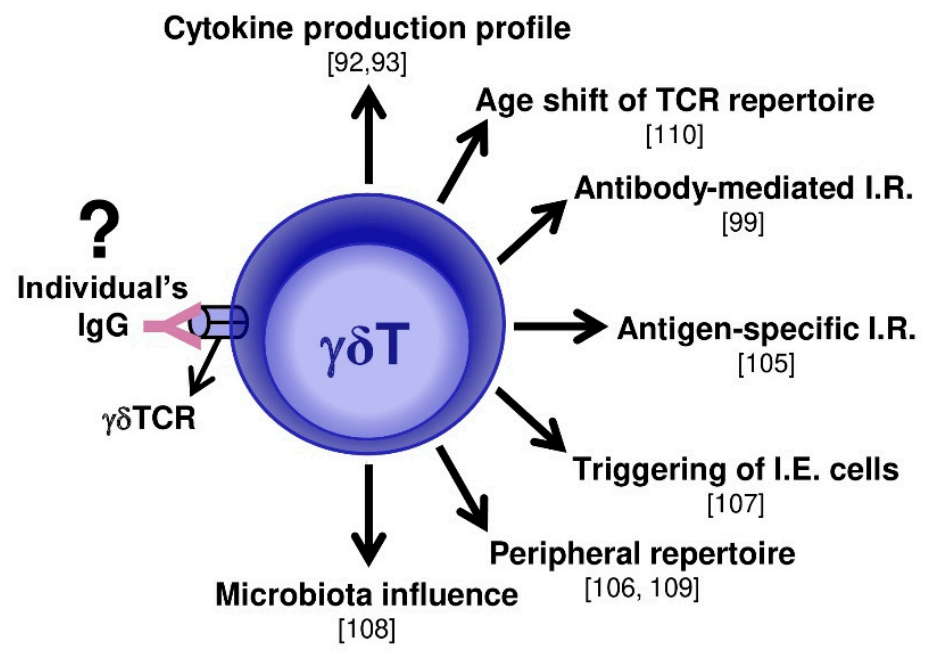

Figure 2. Possible $\gamma \delta$ T cell-mediated mechanisms that can be influenced by IgG. The main immunologic mechanisms mediated by $\gamma \delta \mathrm{T}$ cells described in the literature, where IgG can be an influence by specifically interacting with $\gamma \delta \mathrm{TCRs}$, are illustrated with their respective references in brackets. $?=$ proposed non-evidenced ligand; I.R. = immune response; I.E. = intraepithelial.

\section{Concluding Remarks}

Here we discuss one of the most intriguing unanswered questions of the immune system; indeed, the long period of searching for an efficient response reflects the high degree of difficulty in identifying the natural ligands of $\gamma \delta \mathrm{TCRs}$. Despite the problem, $\gamma \delta \mathrm{T}$ cells already represent a versatile immunoregulatory tool, since they can also be activated through cytokines without TCR engagement, allowing a faster response compared to $\alpha \beta$ T cells. Moreover, they were able to kill target cells via death receptor-mediated apoptosis or the release of cytolytic granules. In this discussion, we seek a broader and philosophical approach about possible $\gamma \delta \mathrm{TCR}$ ligands, not restricted to the physicochemical characteristics of molecular interactions, but considering the complexity of knowledge about the operating range of the immune system. The lack of biological evidence represents the primary limitation on our suggestion about the potential of IgG to answer this "immunological mystery", but if confirmed, IgG molecules acting as a specific ligand of $\gamma \delta$ TCRs can influence several immune mechanisms.

Based on these observations, we can speculate that all the in vivo immunological mechanisms that involve $\gamma \delta$ T cells are subject to influence by the IgG repertoire.

At this point, and maybe still for some years, we cannot be sure that each IgG repertoire has more affinity toward $\gamma \delta$ TCRs. However, considering some breakthrough works in the literature demonstrating the differential effects of IgG repertoires on $\gamma \delta \mathrm{T}, \alpha \beta \mathrm{T}$, and B cells, we can observe a common characteristic that yields some additional speculation about this mechanism. The main described functional effects of IgG repertoires were obtained from chronic pathophysiological conditions 
including allergies [92,93,95,96], atopic dermatitis [94,97], or HIV-1-infected patients [111]. Considering those observations, we suggest that the $\gamma \delta \mathrm{TCR} / \mathrm{IgG}$ affinity determination results form a complex, long-term, and not yet clarified, process.

If confirmed, these can be additional reasons for why such controversial observations about $\gamma \delta \mathrm{T}$ cell functions in the development of several diseases can be observed in the literature. Additionally, the verification of IgG as a ligand of $\gamma \delta \mathrm{TCRs}$ will probably bring this molecule to a position of evidence in studies that aim to investigate immunoregulatory mechanisms involving $\gamma \delta \mathrm{T}$ cells, but under a new perspective where its recognition diversity starts to be considered.

Thus, we hope that the discussed aspects of $\gamma \delta \mathrm{T}$ cell biology can contribute to the future development of advances in antibody-based immunotherapies and vaccines.

Author Contributions: T.R.d.S. wrote the manuscript; J.R.V. proposed and wrote the manuscript. All authors have read and agreed to the published version of the manuscript.

Funding: The execution of this work had the support from the São Paulo Research Foundation (FAPESP) grants \#2019/09741-0 and \#2018/05181-7.

Acknowledgments: We thank LIM-56 for administrative support.

Conflicts of Interest: The authors declare no conflict of interest.

\section{References}

1. Nielsen, M.M.; Witherden, D.A.; Havran, W.L. $\gamma \delta$ T cells in homeostasis and host defence of epithelial barrier tissues. Nat. Rev. Immunol. 2017, 17, 733-745. [CrossRef]

2. Hayday, A.C. Gammadelta T cells and the lymphoid stress-surveillance response. Immunity 2009, 31, $184-196$. [CrossRef] [PubMed]

3. Bonneville, M.; O'Brien, R.L.; Born, W.K. Gammadelta T cell effector functions: A blend of innate programming and acquired plasticity. Nat. Rev. Immunol. 2010, 10, 467-478. [CrossRef] [PubMed]

4. Hayday, A.; Tigelaar, R. Immunoregulation in the tissues by gammadelta T cells. Nat. Rev. Immunol. 2003, 3, 233-242. [CrossRef] [PubMed]

5. Chien, Y.H.; Meyer, C.; Bonneville, M. $\gamma \delta$ T cells: First line of defense and beyond. Annu. Rev. Immunol. 2014, 32, 121-155. [CrossRef] [PubMed]

6. Itohara, S.; Farr, A.G.; Lafaille, J.J.; Bonneville, M.; Takagaki, Y.; Haas, W.; Tonegawa, S. Homing of a gamma delta thymocyte subset with homogeneous T-cell receptors to mucosal epithelia. Nature 1990, 343, 754-757. [CrossRef]

7. Gray, E.E.; Suzuki, K.; Cyster, J.G. Cutting edge: Identification of a motile IL-17-producing gammadelta T cell population in the dermis. J. Immunol. 2011, 186, 6091-6095. [CrossRef]

8. Komori, H.K.; Meehan, T.F.; Havran, W.L. Epithelial and mucosal gamma delta T cells. Curr. Opin. Immunol. 2006, 18, 534-538. [CrossRef]

9. Deusch, K.; Lüling, F.; Reich, K.; Classen, M.; Wagner, H.; Pfeffer, K. A major fraction of human intraepithelial lymphocytes simultaneously expresses the gamma/delta $\mathrm{T}$ cell receptor, the CD8 accessory molecule and preferentially uses the V delta 1 gene segment. Eur. J. Immunol. 1991, 21, 1053-1059. [CrossRef]

10. Kagnoff, M.F. Current concepts in mucosal immunity. III. Ontogeny and function of gamma delta T cells in the intestine. Am. J. Physiol. 1998, 274, G455-G458. [CrossRef]

11. McVay, L.D.; Jaswal, S.S.; Kennedy, C.; Hayday, A.; Carding, S.R. The generation of human gammadelta T cell repertoires during fetal development. J. Immunol. 1998, 160, 5851-5860. [PubMed]

12. Hammerich, L.; Tacke, F. Role of gamma-delta T cells in liver inflammation and fibrosis. World J. Gastrointest. Pathophysiol. 2014, 5, 107-113. [CrossRef] [PubMed]

13. Ajuebor, M.N.; Jin, Y.; Gremillion, G.L.; Strieter, R.M.; Chen, Q.; Adegboyega, P.A. GammadeltaT cells initiate acute inflammation and injury in adenovirus-infected liver via cytokine-chemokine cross talk. J. Virol. 2008, 82, 9564-9576. [CrossRef]

14. Ribot, J.C.; deBarros, A.; Pang, D.J.; Neves, J.F.; Peperzak, V.; Roberts, S.J.; Girardi, M.; Borst, J.; Hayday, A.C.; Pennington, D.J.; et al. CD27 is a thymic determinant of the balance between interferon-gamma- and interleukin 17-producing gammadelta T cell subsets. Nat. Immunol. 2009, 10, 427-436. [CrossRef] [PubMed] 
15. Jensen, K.D.; Su, X.; Shin, S.; Li, L.; Youssef, S.; Yamasaki, S.; Steinman, L.; Saito, T.; Locksley, R.M.; Davis, M.M.; et al. Thymic selection determines gammadelta T cell effector fate: Antigen-naive cells make interleukin-17 and antigen-experienced cells make interferon gamma. Immunity 2008, 29, 90-100. [CrossRef]

16. Puel, A.; Cypowyj, S.; Bustamante, J.; Wright, J.F.; Liu, L.; Lim, H.K.; Migaud, M.; Israel, L.; Chrabieh, M.; Audry, M.; et al. Chronic mucocutaneous candidiasis in humans with inborn errors of interleukin-17 immunity. Science 2011, 332, 65-68. [CrossRef]

17. Conti, H.R.; Peterson, A.C.; Brane, L.; Huppler, A.R.; Hernández-Santos, N.; Whibley, N.; Garg, A.V.; Simpson-Abelson, M.R.; Gibson, G.A.; Mamo, A.J.; et al. Oral-resident natural Th17 cells and $\gamma \delta$ T cells control opportunistic Candida albicans infections. J. Exp. Med. 2014, 211, 2075-2084. [CrossRef]

18. Cho, J.S.; Pietras, E.M.; Garcia, N.C.; Ramos, R.I.; Farzam, D.M.; Monroe, H.R.; Magorien, J.E.; Blauvelt, A.; Kolls, J.K.; Cheung, A.L.; et al. IL-17 is essential for host defense against cutaneous Staphylococcus aureus infection in mice. J. Clin. Investig. 2010, 120, 1762-1773. [CrossRef]

19. Sumaria, N.; Roediger, B.; Ng, L.G.; Qin, J.; Pinto, R.; Cavanagh, L.L.; Shklovskaya, E.; Fazekas de St Groth, B.; Triccas, J.A.; Weninger, W. Cutaneous immunosurveillance by self-renewing dermal gammadelta T cells. J. Exp. Med. 2011, 208, 505-518. [CrossRef]

20. Papotto, P.H.; Reinhardt, A.; Prinz, I.; Silva-Santos, B. Innately versatile: $\gamma \delta 17$ T cells in inflammatory and autoimmune diseases. J. Autoimmun. 2018, 87, 26-37. [CrossRef]

21. Papotto, P.H.; Ribot, J.C.; Silva-Santos, B. IL-17. Nat. Immunol. 2017, 18, 604-611. [CrossRef] [PubMed]

22. Sandrock, I.; Reinhardt, A.; Ravens, S.; Binz, C.; Wilharm, A.; Martins, J.; Oberdörfer, L.; Tan, L.; Lienenklaus, S.; Zhang, B.; et al. Genetic models reveal origin, persistence and non-redundant functions of IL-17-producing $\gamma \delta$ T cells. J. Exp. Med. 2018, 215, 3006-3018. [CrossRef] [PubMed]

23. Wu, D.; Yan, W.M.; Wang, H.W.; Huang, D.; Luo, X.P.; Ning, Q. $\gamma \delta$ T Cells Contribute to the Outcome of Murine Fulminant Viral Hepatitis via Effector Cytokines TNF- $\alpha$ and IFN- $\gamma$. Curr. Med Sci. 2018, 38, 648-655. [CrossRef] [PubMed]

24. He, W.; Hao, J.; Dong, S.; Gao, Y.; Tao, J.; Chi, H.; Flavell, R.; O’Brien, R.L.; Born, W.K.; Craft, J.; et al. Naturally activated $\mathrm{V}$ gamma 4 gamma delta $\mathrm{T}$ cells play a protective role in tumor immunity through expression of eomesodermin. J. Immunol. 2010, 185, 126-133. [CrossRef]

25. Hao, J.; Dong, S.; Xia, S.; He, W.; Jia, H.; Zhang, S.; Wei, J.; O'Brien, R.L.; Born, W.K.; Wu, Z.; et al. Regulatory role of $\mathrm{V} \gamma 1 \gamma \delta \mathrm{T}$ cells in tumor immunity through IL-4 production. J. Immunol. 2011, 187, 4979-4986. [CrossRef] [PubMed]

26. McVay, L.D.; Carding, S.R.; Bottomly, K.; Hayday, A.C. Regulated expression and structure of T cell receptor gamma/delta transcripts in human thymic ontogeny. EMBO J. 1991, 10, 83-91. [CrossRef]

27. McVay, L.D.; Carding, S.R. Extrathymic origin of human gamma delta T cells during fetal development. J. Immunol. 1996, 157, 2873-2882.

28. De Libero, G.; Casorati, G.; Giachino, C.; Carbonara, C.; Migone, N.; Matzinger, P.; Lanzavecchia, A. Selection by two powerful antigens may account for the presence of the major population of human peripheral gamma/delta T cells. J. Exp. Med. 1991, 173, 1311-1322. [CrossRef]

29. Holtmeier, W.; Pfänder, M.; Hennemann, A.; Zollner, T.M.; Kaufmann, R.; Caspary, W.F. The TCR-delta repertoire in normal human skin is restricted and distinct from the TCR-delta repertoire in the peripheral blood. J. Investig. Dermatol. 2001, 116, 275-280. [CrossRef]

30. Hunter, S.; Willcox, C.R.; Davey, M.S.; Kasatskaya, S.A.; Jeffery, H.C.; Chudakov, D.M.; Oo, Y.H.; Willcox, B.E. Human liver infiltrating $\gamma \delta \mathrm{T}$ cells are composed of clonally expanded circulating and tissue-resident populations. J. Hepatol. 2018, 69, 654-665. [CrossRef]

31. Wang, L.; Das, H.; Kamath, A.; Bukowski, J.F. Human V gamma 2V delta 2 T cells produce IFN-gamma and TNF-alpha with an on/off/on cycling pattern in response to live bacterial products. J. Immunol. 2001, 167, 6195-6201. [CrossRef] [PubMed]

32. Minculescu, L.; Sengeløv, H. The role of gamma delta T cells in haematopoietic stem cell transplantation. Scand. J. Immunol. 2015, 81, 459-468. [CrossRef] [PubMed]

33. Adams, E.J.; Gu, S.; Luoma, A.M. Human gamma delta T cells: Evolution and ligand recognition. Cell. Immunol. 2015, 296, 31-40. [CrossRef] [PubMed]

34. Caccamo, N.; Battistini, L.; Bonneville, M.; Poccia, F.; Fournié, J.J.; Meraviglia, S.; Borsellino, G.; Kroczek, R.A.; La Mendola, C.; Scotet, E.; et al. CXCR5 identifies a subset of Vgamma9Vdelta2 T cells which secrete IL-4 and IL-10 and help B cells for antibody production. J. Immunol. 2006, 177, 5290-5295. [CrossRef] [PubMed] 
35. Muñoz-Ruiz, M.; Ribot, J.C.; Grosso, A.R.; Gonçalves-Sousa, N.; Pamplona, A.; Pennington, D.J.; Regueiro, J.R.; Fernández-Malavé, E.; Silva-Santos, B. TCR signal strength controls thymic differentiation of discrete proinflammatory $\gamma \delta \mathrm{T}$ cell subsets. Nat. Immunol. 2016, 17, 721-727. [CrossRef]

36. Fahl, S.P.; Coffey, F.; Kain, L.; Zarin, P.; Dunbrack, R.L.; Teyton, L.; Zúñiga-Pflücker, J.C.; Kappes, D.J.; Wiest, D.L. Role of a selecting ligand in shaping the murine $\gamma \delta$-TCR repertoire. Proc. Natl. Acad. Sci. USA 2018, 115, 1889-1894. [CrossRef]

37. Tonegawa, S.; Berns, A.; Bonneville, M.; Farr, A.; Ishida, I.; Ito, K.; Itohara, S.; Janeway, C.A.; Kanagawa, O.; Katsuki, M. Diversity, development, ligands, and probable functions of gamma delta T cells. Cold Spring Harb. Symp. Quant. Biol. 1989, 54 Pt 1, 31-44. [CrossRef]

38. Tonegawa, S.; Berns, A.; Bonneville, M.; Farr, A.G.; Ishida, I.; Ito, K.; Itohara, S.; Janeway, C.A.; Kanagawa, O.; Kubo, R. Diversity, development, ligands, and probable functions of gamma delta T cells. Adv. Exp. Med. Biol. 1991, 292, 53-61. [CrossRef]

39. Willcox, B.E.; Willcox, C.R. $\gamma \delta$ TCR ligands: The quest to solve a 500-million-year-old mystery. Nat. Immunol. 2019, 20, 121-128. [CrossRef]

40. Bjorkman, P.J.; Saper, M.A.; Samraoui, B.; Bennett, W.S.; Strominger, J.L.; Wiley, D.C. Structure of the human class I histocompatibility antigen, HLA-A2. Nature 1987, 329, 506-512. [CrossRef]

41. Bluestone, J.A.; Jameson, S.; Miller, S.; Dick, R. Peptide-induced conformational changes in class I heavy chains alter major histocompatibility complex recognition. J. Exp. Med. 1992, 176, 1757-1761. [CrossRef] [PubMed]

42. Jorgensen, J.L.; Esser, U.; Fazekas de St Groth, B.; Reay, P.A.; Davis, M.M. Mapping T-cell receptor-peptide contacts by variant peptide immunization of single-chain transgenics. Nature 1992, 355, 224-230. [CrossRef] [PubMed]

43. Rudensky, Y.; Preston-Hurlburt, P.; Hong, S.C.; Barlow, A.; Janeway, C.A. Sequence analysis of peptides bound to MHC class II molecules. Nature 1991, 353, 622-627. [CrossRef] [PubMed]

44. Kropshofer, H.; Max, H.; Müller, C.A.; Hesse, F.; Stevanovic, S.; Jung, G.; Kalbacher, H. Self-peptide released from class II HLA-DR1 exhibits a hydrophobic two-residue contact motif. J. Exp. Med. 1992, 175, 1799-1803. [CrossRef]

45. O'Brien, R.L.; Happ, M.P.; Dallas, A.; Palmer, E.; Kubo, R.; Born, W.K. Stimulation of a major subset of lymphocytes expressing $\mathrm{T}$ cell receptor gamma delta by an antigen derived from Mycobacterium tuberculosis. Cell 1989, 57, 667-674. [CrossRef]

46. Johnson, R.M.; Lancki, D.W.; Sperling, A.I.; Dick, R.F.; Spear, P.G.; Fitch, F.W.; Bluestone, J.A. A murine CD4-, CD8- T cell receptor-gamma delta T lymphocyte clone specific for herpes simplex virus glycoprotein I. J. Immunol. 1992, 148, 983-988.

47. Kozbor, D.; Trinchieri, G.; Monos, D.S.; Isobe, M.; Russo, G.; Haney, J.A.; Zmijewski, C.; Croce, C.M. Human TCR-gamma+/delta+, CD8+ T lymphocytes recognize tetanus toxoid in an MHC-restricted fashion. J. Exp. Med. 1989, 169, 1847-1851. [CrossRef]

48. Chien, Y.H.; Jores, R.; Crowley, M.P. Recognition by gamma/delta T cells. Annu. Rev. Immunol. 1996, 14, 511-532. [CrossRef]

49. Schild, H.; Mavaddat, N.; Litzenberger, C.; Ehrich, E.W.; Davis, M.M.; Bluestone, J.A.; Matis, L.; Draper, R.K.; Chien, Y.H. The nature of major histocompatibility complex recognition by gamma delta T cells. Cell 1994, 76, 29-37. [CrossRef]

50. Weintraub, B.C.; Jackson, M.R.; Hedrick, S.M. Gamma delta T cells can recognize nonclassical MHC in the absence of conventional antigenic peptides. J. Immunol. 1994, 153, 3051-3058.

51. Sciammas, R.; Johnson, R.M.; Sperling, A.I.; Brady, W.; Linsley, P.S.; Spear, P.G.; Fitch, F.W.; Bluestone, J.A. Unique antigen recognition by a herpesvirus-specific TCR-gamma delta cell. J. Immunol. 1994, 152, 5392-5397. [PubMed]

52. Turchinovich, G.; Pennington, D.J. T cell receptor signalling in $\gamma \delta$ cell development: Strength isn't everything. Trends Immunol. 2011, 32, 567-573. [CrossRef] [PubMed]

53. Mahtani-Patching, J.; Neves, J.F.; Pang, D.J.; Stoenchev, K.V.; Aguirre-Blanco, A.M.; Silva-Santos, B.; Pennington, D.J. PreTCR and TCR $\gamma \delta$ signal initiation in thymocyte progenitors does not require domains implicated in receptor oligomerization. Sci. Signal. 2011, 4, ra47. [CrossRef] [PubMed] 
54. Crowley, M.P.; Fahrer, A.M.; Baumgarth, N.; Hampl, J.; Gutgemann, I.; Teyton, L.; Chien, Y. A population of murine gammadelta T cells that recognize an inducible MHC class Ib molecule. Science 2000, 287, 314-316. [CrossRef]

55. Luoma, A.M.; Castro, C.D.; Mayassi, T.; Bembinster, L.A.; Bai, L.; Picard, D.; Anderson, B.; Scharf, L.; Kung, J.E.; Sibener, L.V.; et al. Crystal structure of V $\delta 1 \mathrm{~T}$ cell receptor in complex with CD1d-sulfatide shows MHC-like recognition of a self-lipid by human $\gamma \delta$ T cells. Immunity 2013, 39, 1032-1042. [CrossRef] [PubMed]

56. Uldrich, A.P.; Le Nours, J.; Pellicci, D.G.; Gherardin, N.A.; McPherson, K.G.; Lim, R.T.; Patel, O.; Beddoe, T.; Gras, S.; Rossjohn, J.; et al. CD1d-lipid antigen recognition by the $\gamma \delta$ TCR. Nat. Immunol. 2013, 14, 1137-1145. [CrossRef]

57. Willcox, C.R.; Pitard, V.; Netzer, S.; Couzi, L.; Salim, M.; Silberzahn, T.; Moreau, J.F.; Hayday, A.C.; Willcox, B.E.; Déchanet-Merville, J. Cytomegalovirus and tumor stress surveillance by binding of a human $\gamma \delta \mathrm{T}$ cell antigen receptor to endothelial protein $C$ receptor. Nat. Immunol. 2012, 13, 872-879. [CrossRef]

58. Xu, B.; Pizarro, J.C.; Holmes, M.A.; McBeth, C.; Groh, V.; Spies, T.; Strong, R.K. Crystal structure of a gammadelta T-cell receptor specific for the human MHC class I homolog MICA. Proc. Natl. Acad. Sci. USA 2011, 108, 2414-2419. [CrossRef]

59. Collins, C.; Lui, Y.; Santos, A.M.; Ballif, B.A.; Gogerly-Moragoda, A.M.; Brouwer, H.; Ross, R.; Balagurunathan, K.; Sharma, S.; Wright, G.J.; et al. Detection of Cell Surface Ligands for Human Synovial $\gamma \delta$ T Cells. J. Immunol. 2019. [CrossRef]

60. Melandri, D.; Zlatareva, I.; Chaleil, R.A.G.; Dart, R.J.; Chancellor, A.; Nussbaumer, O.; Polyakova, O.; Roberts, N.A.; Wesch, D.; Kabelitz, D.; et al. The $\gamma \delta \mathrm{TCR}$ combines innate immunity with adaptive immunity by utilizing spatially distinct regions for agonist selection and antigen responsiveness. Nat. Immunol. 2018, 19, 1352-1365. [CrossRef]

61. Nakada, E.M.; Shan, J.; Kinyanjui, M.W.; Fixman, E.D. Adjuvant-dependent regulation of interleukin-17 expressing $\gamma \delta \mathrm{T}$ cells and inhibition of Th2 responses in allergic airways disease. Respir. Res. 2014, 15, 90. [CrossRef] [PubMed]

62. Gu, S.; Nawrocka, W.; Adams, E.J. Sensing of Pyrophosphate Metabolites by V $\gamma 9$ V $\delta 2$ T Cells. Front. Immunol. 2014, 5, 688. [CrossRef] [PubMed]

63. Tanaka, Y.; Morita, C.T.; Nieves, E.; Brenner, M.B.; Bloom, B.R. Natural and synthetic non-peptide antigens recognized by human gamma delta T cells. Nature 1995, 375, 155-158. [CrossRef] [PubMed]

64. Wang, H.; Henry, O.; Distefano, M.D.; Wang, Y.C.; Räikkönen, J.; Mönkkönen, J.; Tanaka, Y.; Morita, C.T. Butyrophilin 3A1 plays an essential role in prenyl pyrophosphate stimulation of human $\mathrm{V} \gamma 2 \mathrm{~V} \delta 2 \mathrm{~T}$ cells. J. Immunol. 2013, 191, 1029-1042. [CrossRef] [PubMed]

65. Scotet, E.; Martinez, L.O.; Grant, E.; Barbaras, R.; Jenö, P.; Guiraud, M.; Monsarrat, B.; Saulquin, X.; Maillet, S.; Estève, J.P.; et al. Tumor recognition following Vgamma9Vdelta2 $\mathrm{T}$ cell receptor interactions with a surface F1-ATPase-related structure and apolipoprotein A-I. Immunity 2005, 22, 71-80. [CrossRef]

66. Zeng, X.; Wei, Y.L.; Huang, J.; Newell, E.W.; Yu, H.; Kidd, B.A.; Kuhns, M.S.; Waters, R.W.; Davis, M.M.; Weaver, C.T.; et al. $\gamma \delta \mathrm{T}$ cells recognize a microbial encoded B cell antigen to initiate a rapid antigen-specific interleukin-17 response. Immunity 2012, 37, 524-534. [CrossRef]

67. Marlin, R.; Pappalardo, A.; Kaminski, H.; Willcox, C.R.; Pitard, V.; Netzer, S.; Khairallah, C.; Lomenech, A.M.; Harly, C.; Bonneville, M.; et al. Sensing of cell stress by human $\gamma \delta$ TCR-dependent recognition of annexin A2. Proc. Natl. Acad. Sci. USA 2017, 114, 3163-3168. [CrossRef]

68. Harly, C.; Guillaume, Y.; Nedellec, S.; Peigné, C.M.; Mönkkönen, H.; Mönkkönen, J.; Li, J.; Kuball, J.; Adams, E.J.; Netzer, S.; et al. Key implication of CD277/butyrophilin-3 (BTN3A) in cellular stress sensing by a major human $\gamma \delta$ T-cell subset. Blood 2012, 120, 2269-2279. [CrossRef]

69. Blazquez, J.L.; Benyamine, A.; Pasero, C.; Olive, D. New Insights into the Regulation of $\gamma \delta$ T Cells by BTN3A and Other BTN/BTNL in Tumor Immunity. Front. Immunol. 2018, 9, 1601. [CrossRef]

70. Adams, E.J.; Chien, Y.H.; Garcia, K.C. Structure of a gammadelta T cell receptor in complex with the nonclassical MHC T22. Science 2005, 308, 227-231. [CrossRef]

71. Chien, Y.H.; Konigshofer, Y. Antigen recognition by gammadelta T cells. Immunol. Rev. 2007, 215 , 46-58. [CrossRef] [PubMed] 
72. Bai, L.; Picard, D.; Anderson, B.; Chaudhary, V.; Luoma, A.; Jabri, B.; Adams, E.J.; Savage, P.B.; Bendelac, A. The majority of CD1d-sulfatide-specific T cells in human blood use a semiinvariant V 1 TCR. Eur. J. Immunol. 2012, 42, 2505-2510. [CrossRef] [PubMed]

73. Roy, S.; Ly, D.; Castro, C.D.; Li, N.S.; Hawk, A.J.; Altman, J.D.; Meredith, S.C.; Piccirilli, J.A.; Moody, D.B.; Adams, E.J. Molecular Analysis of Lipid-Reactive V $\delta 1 \gamma \delta$ T Cells Identified by CD1c Tetramers. J. Immunol. 2016, 196, 1933-1942. [CrossRef] [PubMed]

74. Zeng, X.; Meyer, C.; Huang, J.; Newell, E.W.; Kidd, B.A.; Wei, Y.L.; Chien, Y.H. Gamma delta T cells recognize haptens and mount a hapten-specific response. eLife 2014, 3, e03609. [CrossRef] [PubMed]

75. Pfeffer, K.; Schoel, B.; Gulle, H.; Kaufmann, S.H.; Wagner, H. Primary responses of human T cells to mycobacteria: A frequent set of gamma/delta T cells are stimulated by protease-resistant ligands. Eur. J. Immunol. 1990, 20, 1175-1179. [CrossRef]

76. Tanaka, Y.; Sano, S.; Nieves, E.; De Libero, G.; Rosa, D.; Modlin, R.L.; Brenner, M.B.; Bloom, B.R.; Morita, C.T. Nonpeptide ligands for human gamma delta T cells. Proc. Natl. Acad. Sci. USA 1994, 91, 8175-8179. [CrossRef]

77. Groh, V.; Steinle, A.; Bauer, S.; Spies, T. Recognition of stress-induced MHC molecules by intestinal epithelial gammadelta T cells. Science 1998, 279, 1737-1740. [CrossRef]

78. Groh, V.; Rhinehart, R.; Secrist, H.; Bauer, S.; Grabstein, K.H.; Spies, T. Broad tumor-associated expression and recognition by tumor-derived gamma delta T cells of MICA and MICB. Proc. Natl. Acad. Sci. USA 1999, 96, 6879-6884. [CrossRef]

79. Wu, J.; Groh, V.; Spies, T. T cell antigen receptor engagement and specificity in the recognition of stress-inducible MHC class I-related chains by human epithelial gamma delta T cells. J. Immunol. 2002, 169, 1236-1240. [CrossRef]

80. Kong, Y.; Cao, W.; Xi, X.; Ma, C.; Cui, L.; He, W. The NKG2D ligand ULBP4 binds to TCRgamma9/delta2 and induces cytotoxicity to tumor cells through both TCRgammadelta and NKG2D. Blood 2009, 114, 310-317. [CrossRef]

81. Kim, H.T.; Nelson, E.L.; Clayberger, C.; Sanjanwala, M.; Sklar, J.; Krensky, A.M. Gamma delta T cell recognition of tumor Ig peptide. J. Immunol. 1995, 154, 1614-1623. [PubMed]

82. Zhang, L.; Jin, N.; Nakayama, M.; O'Brien, R.L.; Eisenbarth, G.S.; Born, W.K. Gamma delta T cell receptors confer autonomous responsiveness to the insulin-peptide B:9-23. J. Autoimmun. 2010, 34, 478-484. [CrossRef] [PubMed]

83. Bruder, J.; Siewert, K.; Obermeier, B.; Malotka, J.; Scheinert, P.; Kellermann, J.; Ueda, T.; Hohlfeld, R.; Dornmair, K. Target specificity of an autoreactive pathogenic human $\gamma \delta$-T cell receptor in myositis. J. Biol. Chem. 2012, 287, 20986-20995. [CrossRef] [PubMed]

84. Ariizumi, K.; Shen, G.L.; Shikano, S.; Xu, S.; Ritter, R.; Kumamoto, T.; Edelbaum, D.; Morita, A.; Bergstresser, P.R.; Takashima, A. Identification of a novel, dendritic cell-associated molecule, dectin-1, by subtractive cDNA cloning. J. Biol. Chem. 2000, 275, 20157-20167. [CrossRef]

85. Martin, B.; Hirota, K.; Cua, D.J.; Stockinger, B.; Veldhoen, M. Interleukin-17-producing gammadelta T cells selectively expand in response to pathogen products and environmental signals. Immunity 2009, 31, 321-330. [CrossRef]

86. Rao, R.; Graffeo, C.S.; Gulati, R.; Jamal, M.; Narayan, S.; Zambirinis, C.P.; Barilla, R.; Deutsch, M.; Greco, S.H.; Ochi, A.; et al. Interleukin 17-producing $\gamma \delta \mathrm{T}$ cells promote hepatic regeneration in mice. Gastroenterology 2014, 147, 473-484.e472. [CrossRef]

87. Koenecke, C.; Chennupati, V.; Schmitz, S.; Malissen, B.; Förster, R.; Prinz, I. In vivo application of mAb directed against the gammadelta TCR does not deplete but generates "invisible" gammadelta T cells. Eur. J. Immunol. 2009, 39, 372-379. [CrossRef]

88. Kang, N.; Zhou, J.; Zhang, T.; Wang, L.; Lu, F.; Cui, Y.; Cui, L.; He, W. Adoptive immunotherapy of lung cancer with immobilized anti-TCRgammadelta antibody-expanded human gammadelta T-cells in peripheral blood. Cancer Biol. Ther. 2009, 8, 1540-1549. [CrossRef]

89. Zhou, J.; Kang, N.; Cui, L.; Ba, D.; He, W. Anti- $\gamma \delta$ TCR antibody-expanded $\gamma \delta$ T cells: A better choice for the adoptive immunotherapy of lymphoid malignancies. Cell. Mol. Immunol. 2012, 9, 34-44. [CrossRef]

90. Victor, J.R. Allergen-specific IgG as a mediator of allergy inhibition: Lessons from mother to child. Hum. Vaccines Immunother. 2017, 13, 507-513. [CrossRef] 
91. Jerne, N.K. Idiotypic networks and other preconceived ideas. Immunol. Rev. 1984, 79, 5-24. [CrossRef] [PubMed]

92. De Oliveira, M.G.; de Lima Lira, A.A.; da Ressureição Sgnotto, F.; Inoue, A.H.S.; Santos, L.S.; Nakamatsu, B.Y.; Duarte, A.J.D.S.; Leite-de-Moraes, M.; Victor, J.R. Maternal IgG impairs the maturation of offspring intrathymic IL-17-producing $\gamma \delta$ T cells: Implications for murine and human allergies. Clin. Exp. Allergy 2019, 49, 1000-1012. [CrossRef]

93. Santos, L.S.; Sgnotto, F.D.R.; Inoue, A.H.S.; Padreca, A.F.; Menghini, R.P.; Duarte, A.J.D.S.; Victor, J.R. IgG from Non-atopic Individuals Induces In Vitro IFN- $\gamma$ and IL-10 Production by Human Intra-thymic $\gamma \delta \mathrm{T}$ Cells: A Comparison with Atopic IgG and IVIg. Arch. Immunol. Ther. Exp. (Warsz) 2019, 67, 263-270. [CrossRef] [PubMed]

94. Sgnotto, F.D.R.; de Oliveira, M.G.; Lira, A.A.L.; Inoue, A.H.S.; Titz, T.O.; Orfali, R.L.; Bento-de-Souza, L.; Sato, M.N.; Aoki, V.; Duarte, A.J.S.; et al. IgG from atopic dermatitis patients induces IL-17 and IL-10 production in infant intrathymic TCD4 and TCD8 cells. Int. J. Dermatol. 2018, 57, 434-440. [CrossRef] [PubMed]

95. De Oliveira, M.G.; Oliveira, L.D.M.; de Lima Lira, A.A.; Sgnotto, F.D.R.; da Silva Duarte, A.J.; Sato, M.N.; Victor, J.R. Preconception allergen sensitization can induce B10 cells in offspring: A potential main role for maternal IgG. Allergy Asthma Clin. Immunol. 2017, 13, 22. [CrossRef] [PubMed]

96. Sgnotto, F.D.R.; Oliveira, M.G.; Lira, A.A.L.; Bento-de-Souza, L.; Duarte, A.J.D.S.; Victor, J.R. Low doses of IgG from atopic individuals can modulate in vitro IFN- $\gamma$ production by human intra-thymic TCD4 and TCD8 cells: An IVIg comparative approach. Hum. Vaccines Immunother. 2017, 13, 1563-1572. [CrossRef] [PubMed]

97. Santos, L.S.; Sgnotto, F.D.R.; Sousa, T.R.; Orfali, R.L.; Aoki, V.; Duarte, A.J.D.S.; Victor, J.R. IgG from atopic dermatitis patients induces non-atopic infant thymic invariant natural killer T (iNKT) cells to produce IL-4, IL-17, and IL-10. Int. J. Dermatol. 2019. [CrossRef]

98. Futata, E.; de Brito, C.; Victor, J.; Fusaro, A.; Oliveira, C.; Maciel, M.; Duarte, A.; Sato, M. Long-term anergy in orally tolerized mice is linked to decreased B7.2 expression on B cells. Immunobiology 2006, 211, 157-166. [CrossRef]

99. Rezende, R.M.; Lanser, A.J.; Rubino, S.; Kuhn, C.; Skillin, N.; Moreira, T.G.; Liu, S.; Gabriely, G.; David, B.A.; Menezes, G.B.; et al. $\gamma \delta \mathrm{T}$ cells control humoral immune response by inducing $\mathrm{T}$ follicular helper cell differentiation. Nat. Commun. 2018, 9, 3151. [CrossRef]

100. Chen, S.T. Cellular sites of immunoglobulins. I. Distribution of light polypeptide chains in human lymphoid tissue. Acta Pathol. Jpn. 1970, 20, 487-503.

101. Chen, S.T.; Izui, S. Cellular sites of immunoglobulins. 3. Localization of IgG-, IgA-, IgM- and their kappa and lambda light chain-containing cells in human palatine tonsils. Acta Pathol. Jpn. 1971, 21, 85-92. [PubMed]

102. Chen, S.T. Cellular sites of immunoglobulins. II. The relative proportions of mucosal cells containing IgG, IgA, and IgM, and light polypeptide chains of kappa and lambda immunoglobulin in human appendices. Acta Pathol. Jpn. 1971, 21, 67-83. [PubMed]

103. Chen, S.T.; Tobe, T.; Iosobe, Y.; Chiu, A.F. Cellular sites of immunoglobulins. VI. Localization of immunoglobulins in the human thymus. Acta Pathol. Jpn. 1975, 25, 69-73. [CrossRef] [PubMed]

104. Victor, J.R. Do different IgG repertoires play a role in B- and T-cell functional modulation during ontogeny? The "hooks without bait" theory. Immunol. Cell Biol. 2020. [CrossRef]

105. Belkadi, A.; Dietrich, C.; Machavoine, F.; Victor, J.R.; Leite-de-Moraes, M. $\gamma \delta \mathrm{T}$ cells amplify Blomia tropicalis-induced allergic airway disease. Allergy 2018. [CrossRef]

106. Cheng, C.; Wang, B.; Gao, L.; Liu, J.; Chen, X.; Huang, H.; Zhao, Z. Next generation sequencing reveals changes of the $\gamma \delta \mathrm{T}$ cell receptor repertoires in patients with pulmonary tuberculosis. Sci. Rep. 2018, 8, 3956. [CrossRef]

107. Malinarich, F.H.; Grabski, E.; Worbs, T.; Chennupati, V.; Haas, J.D.; Schmitz, S.; Candia, E.; Quera, R.; Malissen, B.; Förster, R.; et al. Constant TCR triggering suggests that the TCR expressed on intestinal intraepithelial $\gamma \delta \mathrm{T}$ cells is functional in vivo. Eur. J. Immunol. 2010, 40, 3378-3388. [CrossRef]

108. Tedesco, D.; Thapa, M.; Chin, C.Y.; Ge, Y.; Gong, M.; Li, J.; Gumber, S.; Speck, P.; Elrod, E.J.; Burd, E.M.; et al. Alterations in Intestinal Microbiota Lead to Production of Interleukin 17 by Intrahepatic $\gamma \delta$ T-Cell Receptor-Positive Cells and Pathogenesis of Cholestatic Liver Disease. Gastroenterology 2018, 154, 2178-2193. [CrossRef] 
109. Jensen, K.D.; Shin, S.; Chien, Y.H. Cutting edge: Gammadelta intraepithelial lymphocytes of the small intestine are not biased toward thymic antigens. J. Immunol. 2009, 182, 7348-7351. [CrossRef]

110. Kallemeijn, M.J.; Kavelaars, F.G.; van der Klift, M.Y.; Wolvers-Tettero, I.L.M.; Valk, P.J.M.; van Dongen, J.J.M.; Langerak, A.W. Next-Generation Sequencing Analysis of the Human TCR $\gamma \delta+$ T-Cell Repertoire Reveals Shifts in V $\gamma$ - and V $\delta$-Usage in Memory Populations upon Aging. Front. Immunol. 2018, 9, 448. [CrossRef]

111. Da Ressureição Sgnotto, F.; Souza Santos, L.; Rodrigues de Sousa, T.; Feitosa de Lima, J.; Mara da Silva Oliveira, L.; Saeed Sanabani, S.; José da Silva Duarte, A.; Russo Victor, J. IgG from HIV-1-Exposed Seronegative and HIV-1-Infected Subjects Differently Modulates IFN- $\gamma$ Production by Thymic T and B Cells. J. Acquir. Immune Defic. Syndr. 2019, 82, e56-e60. [CrossRef] [PubMed]

(C) 2020 by the authors. Licensee MDPI, Basel, Switzerland. This article is an open access article distributed under the terms and conditions of the Creative Commons Attribution (CC BY) license (http://creativecommons.org/licenses/by/4.0/). 